\title{
Syskonjordbruk som en historisk fråga
}

\section{Kvarstannarna}

När riksdagsledamoten Cecilia Wikström 2006 väckte förslag om en svensk litteraturkanon, en lista över svensk litteratur som alla borde läsa redan i skolåldern, uppstod snabbt en debatt både om behovet av en sådan lista och om vilka verk som i så fall borde upptas på densamma. Även om förslaget aldrig vann gehör visade debatten att en romansvit intog en särställning: Vilhelm Mobergs stora utvandrarepos. ${ }^{1}$ Litteraturvetaren Jens Liljestrand menar att debatten närmast bekräftade att Mobergs utvandrarserie i praktiken varit kanoniserad alltsedan den publicerades. Förhållandet härleder han ur ett samspel mellan läsare, kritiker, författare och förlag. Verket fick en stark ställning både som en välansedd kritikerhyllad klassiker och som en kommersiellt framgångsrik "folkbok".

Mobergs skildring av utvandrarnas nya liv i Amerika är givetvis en central del av romanerna, men böckerna gör också anspråk på att förmedla en bild av Sverige och inte minst den svenske bondens liv. Spänningen mellan det nya och det gamla löper som en röd tråd genom romansviten, och att huvudpersonerna slits mellan att stanna i det hemtama och att bryta upp och lämna allt utgör ett bärande tema. Det framträder allra starkast i Kristinas hemlängtan till Sverige och sin barndomsmiljö i Duvemåla. Redan i de berömda första raderna i Utvandrarna mejslar Moberg fram spänningen mellan att stanna och att lämna:

De var de första som utflyttade från sin ort. De kom från de små stugornas och de stora barnkullarnas land. De var jordens folk och 
de kom från en släkt, som sedan årtusenden hade brukat den jord de lämnade. Släktleden hade bytt av varandra: sonen trädde till efter fadern vid harv och årder, och dottern tog moderns plats vid spinnrock och vävstol. Genom alla skiften förblev gården släktens hem och givaren av livets uppehälle. ${ }^{3}$

I passagen ovan understryker Moberg uppbrottets betydelse ur ett långt tidsperspektiv, men också trögheten i ett gammalt bondesamhälle där generationerna löst av varandra. Samtidigt finns något motsägelsefullt i allt det orörliga. Karl Oskar tog visserligen över efter fadern Nils på Korpamoen, men även om Kristina gick i sin mor Annas fotspår och blev bondmora så övertog hon inte hennes plats i föräldrahemmet i Duvemåla. Att sonen tog vid efter fadern och dottern efter modern bör förstås bildligt, inte bokstavligt. Även det trögrörliga gamla bondesamhället förutsatte en viss rotation.

När musikalen Kristina från Duvemåla lanserades 1995 fick Mobergs romaner en ny glansperiod och det ökade intresset märktes inte minst lokalt i de småländska bygder där berättelsen utspelar sig. På grund av musikalens namn lockades stora strömmar av turister till Duvemåla, en liten oansenlig by strax norr om Emmaboda i södra Småland. För att möta det ökade intresset inrättade kommunen snart ett museum på en ålderdomlig gård i byn. ${ }^{4}$ Den som i dag besöker Duvemåla kan därför få en guidning i Mobergs författarskap och "Kristinas Duvemåla" såsom det skildras i böckerna och musikalen, komplett med gunga, astrakan och en scenförsedd Duvemåla hage.

Det är dock bara övervåningen i den gamla småländska parstugan som behandlar Moberg och utvandrarsviten. Bottenvåningen är tillägnad gårdens tidigare ägare, de fyra syskonen Rundqvist. Här levde och arbetade Herta, Martin, Mauritz och Naëmi Rundqvist hela sina liv, innan kommunen efter deras död förvärvade fastigheten. Kontrasten mellan de två utställningarna i Duvemåla är slående. Berättelsen om utvandrarna handlar om dem som gav sig av. Det utmärkande för syskonen Rundqvist var istället att de stannade inte bara i landet utan även i föräldrahemmet. Utställningen över deras liv är ett tämligen unikt dokument över en syskonskara med 


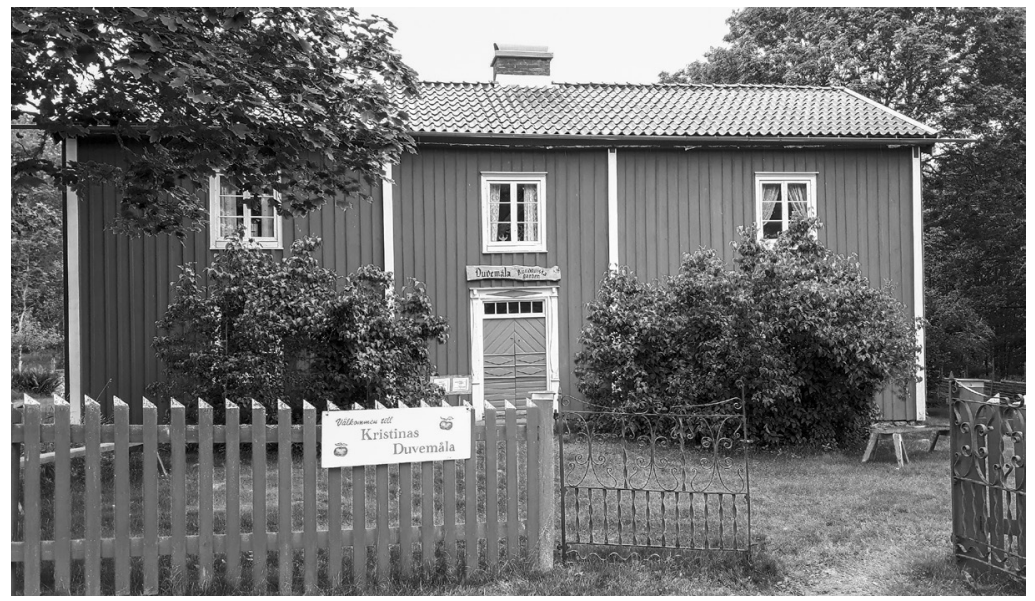

Skylten vid museet välkomnar till Kristinas Duvemåla. Att Moberg valde just Duvemåla som Kristinas födelseplats hade sannolikt personliga skäl; hans mormor var född i huset mittemot. Det är i dag rivet. Foto: författaren.

ett kollektivt levnadsöde. ${ }^{5}$ I deras fall kan Mobergs skildring av hur generationerna bytte av varandra tolkas bokstavligt: sönerna tog faderns plats, döttrarna moderns.

I denna bok kommer syskonjordbruk som det i Duvemåla att stå i centrum. Med denna beteckning avses i det följande syskon som bott ihop och tillsammans drivit jordbruk. ${ }^{6}$ Vad som utmärkte dem, hur vanliga de var och varför de uppstod kommer att vara viktiga frågor. För att fördjupa förståelsen av vad ett syskonjordbruk egentligen var finns inledningsvis skäl att ge en mer utförlig beskrivning av syskonen Rundqvists levnadsöde.

\section{De fyra från Duvemåla}

Historien om syskonen Rundqvist kan göras kort och enkel. Gården i Duvemåla köptes av deras morföräldrar och ärvdes så småningom av syskonens mor Emma. Hon gifte sig vid sekelskiftet 1900 med Karl Rundqvist och de fyra barnen föddes mellan 1902 och 1909. Vad som därpå följde var att det just inte hände särskilt mycket. När föräldrarna gick bort 1948 respektive 1952 fanns de fyra 


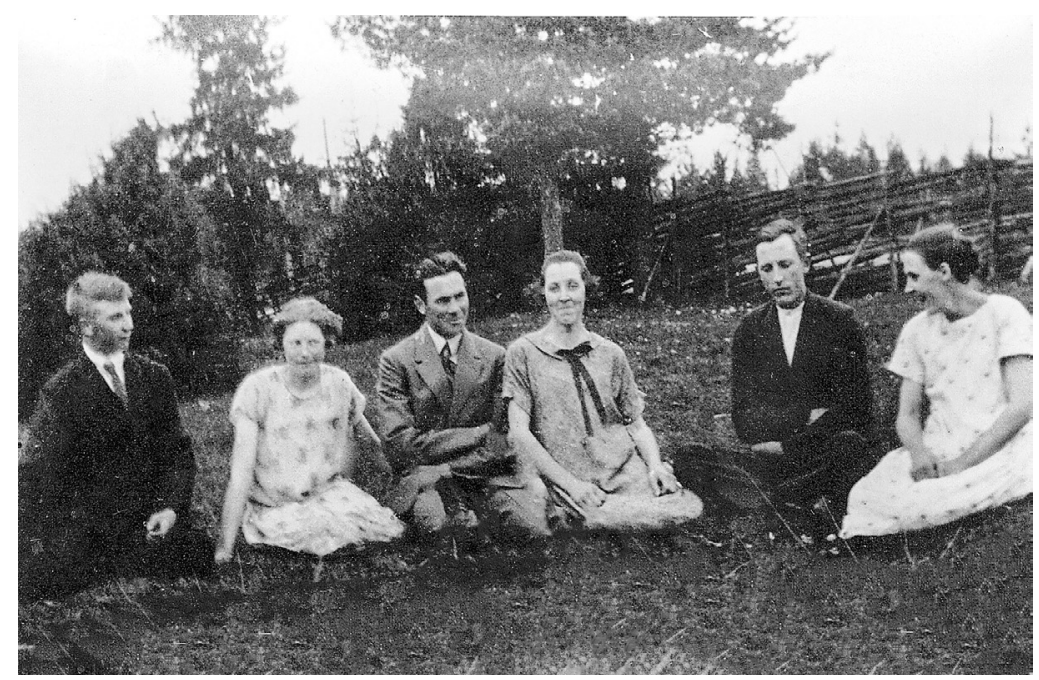

Syskonen Rundqvist: Mauritz (längst t.v.), och från höger Naëmi, Martin och Herta. Mannen i mitten ska under en tid ha sällskapat med Herta. Det blev dock aldrig något giftermål. Kvinnan till höger om Mauritz är okänd. Foto: okänd.

ogifta barnen fortfarande kvar på gården. Vid arvskiftet delades fastigheten på pappret i fyra lika stora delar, men i praktiken hölls den ihop som en enhet. Både ägande- och boendeförhållandena förblev därefter intakta tills syskonen under 1980-talets lopp gick ur tiden. När den siste i skaran, Mauritz, 1989 slöt sina dagar på Algutsboda ålderdomshem tillföll hela kvarlåtenskapen Allmänna arvsfonden. Något år senare förvärvade Emmaboda kommun egendomen, huvudsakligen för dess naturvärden. ${ }^{7}$ Med musikalen och det växande intresset för Duvemåla by ändrades dock förutsättningarna i grunden.

Till denna kortfattade levnadshistoria kan dock läggas mer berättande inslag. I museets informationsbroschyr sägs att de fyra syskonen "med eller mot sin vilja" fjättrade sig vid sin gård och skötte allt enligt ålderdomliga principer. Elektricitet, rinnande vatten, avlopp, telefon och tv fann aldrig sin väg till gården. Moderniseringen av jordbruket uteblev och allt arbete utfördes med häst eller handkraft. ${ }^{8}$ När det efter syskonens död uppdagades att deras förmögenhet uppgått till närmare sex miljoner kronor och att det fanns pengar 


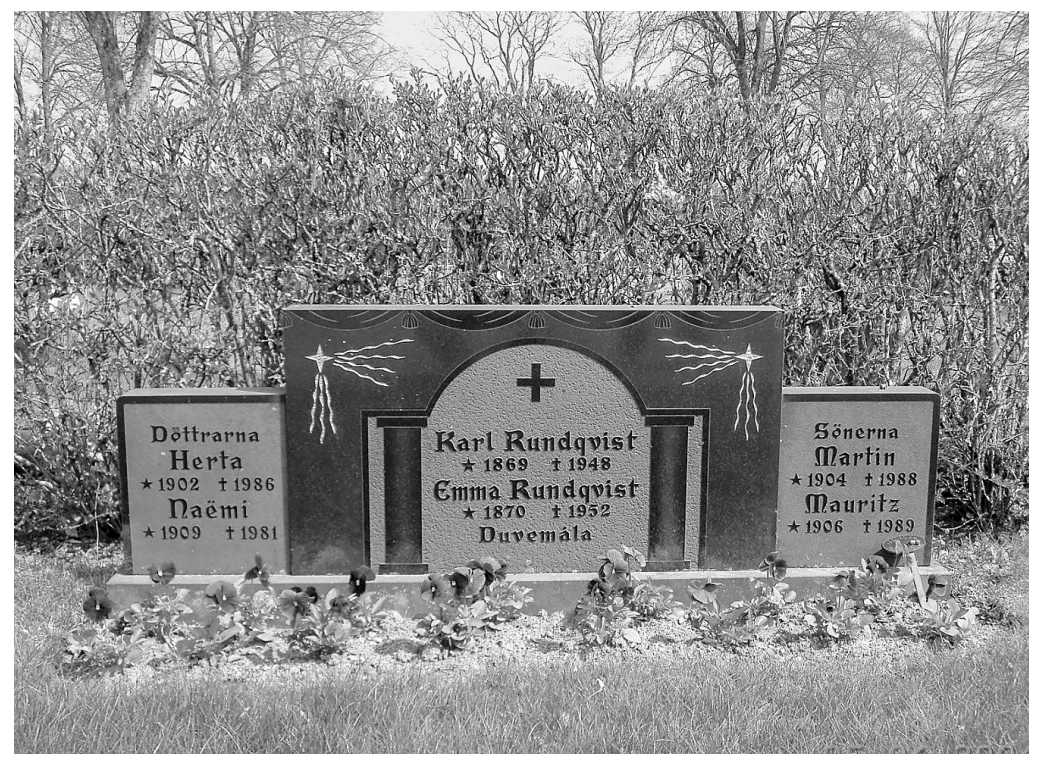

Familjen Rundqvists gravvård på Algutsboda kyrkogård. Systrarna har placerats på en sida, sönerna på den andra. Notera att ordningsföljden utgår från syskonens plats i syskonskaran, inte dödsåret. Foto: författaren.

undanstoppade på åtskilliga platser i både boningshus och uthus tilldrog sig syskonens levnadsöde ett mer allmänt intresse. Enligt en artikel som främst bygger på samtal med grannar i byn hade föräldrarna setts som storbondefolk av den gamla stammen som gärna såg sig som lite förmer än andra. Det var sådana skäl som gjorde att fadern stoppade dottern Hertas förlovning med en $\mathrm{i}$ hans tycke ekonomiskt olämplig kavaljer. Någon vilja att följa med den tekniska utvecklingen för att därigenom upprätthålla sin ställning tycks de dock inte ha haft. ${ }^{9}$ Trots ett relativt stort boningshus levde syskonen huvudsakligen i ett rum och kök. ${ }^{10}$ Efter hand slöt de sig allt mer till varandra och förde ett mycket tillbakadraget liv, präglat av en tydlig rangordning syskonen emellan. ${ }^{11}$ Denna hierarki anas även vid syskonens gravvård, där de delas upp efter kön och plats i syskonskaran. 


\section{Från Duvemåla till Änglagård}

Berättelsen om syskonen Rundqvist rymmer flera bottnar: de levde ett mycket ålderdomligt liv, stoppade pengar i madrassen och bodde dessutom avskilt utan större kontakter med omvärlden. Den mest iögonfallande aspekten av deras levnadsöde är dock att de aldrig på allvar lämnade gården utan bildade ett gemensamt hushåll livet igenom. Utställningen i Duvemåla är ett av Sveriges få museer över ett syskonjordbruk. ${ }^{12}$ Företeelsen finns dock belagd på andra håll. I boken Den siste bonden på Tämmesboda ger fotografen och författaren Lars-Olof Hallberg en dokumentation av livet på den lilla arrendegård där syskonen Stig och Berit Aronsson levt hela sitt liv. ${ }^{13}$ Bo Larsson har i en annan studie följt ett arbetsår på ett syskonjordbruk med två systrar och en bror på ett värmländskt småbruk. ${ }^{14}$ Filmaren och fotografen Peter Gerdehag - som tidigare rönt uppmärksamhet med filmer som Bondens tid på jorden, Hästmannen och Kokvinnorna - utkom 2012 med dokumentären Landet som inte längre är, där han summerar 36 års dokumentation av vardagslivet hos familjen Caremalm på ett småbruk utanför Oskarshamn. Jordbruket på Kroxhult 1:4 bedrevs gemensamt av bröderna Sture och Karl-Uno, men Sture var gift och hade familj. ${ }^{15}$

Det mest välkända syskonjordbruket är dock sannolikt de småländska bröderna Erik och Sigvard, som 1992 blev riksbekanta genom en serie dokumentära porträtt på SVT, så småningom samlade i filmen Erik och Sigvard. Ett år i Småland. ${ }^{16}$ De blev därefter också uppmärksammade i ett flertal böcker. ${ }^{17}$ Erik och Sigvard var mellanbarn i en stor barnaskara om totalt åtta syskon. Det var dock bara de två som blev kvar på gården, som de drev med gamla metoder och i nära samklang med naturen. ${ }^{18}$ Samma år som Erik och Sigvard dök upp i tv introducerades ett annat ruralt brödrapar i en av decenniets största filmsuccéer. Colin Nutleys Änglagård handlar visserligen primärt om Fanny och Zac och deras möte med en konservativ landsbygd, men en nyckelroll i handlingen har de gamla bröderna Ivar och Gottfrid, så till den grad oskiljaktiga att de sov med sängarna intill varandra.

Gottfrid och Ivar är förvisso fiktiva, men karaktärerna bygger delvis på ett verkligt brödrapar i Västergötland som Nutley lärde 


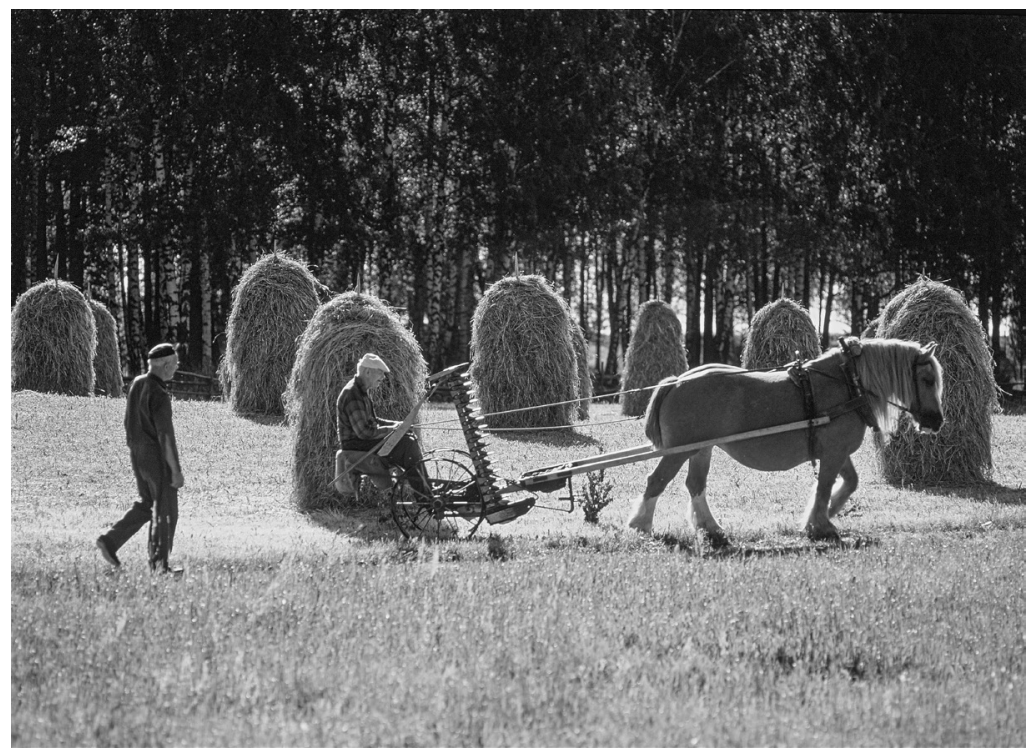

Erik och Sigvard bland höhässjorna på gården i Hågeryd och med hästen Donna spänd framför slåttermaskinen. Foto: Torsten Axelsson.

känna. ${ }^{19}$ Det tycks med andra ord inte saknas exempel på att syskonjordbruk existerat. Att de har porträtterats beror dock inte i första hand på själva syskonrelationen. Ambitionen med de nämnda exemplen - de fiktiva Ivar och Gottfrid undantagna - är snarare att dokumentera jordbruk som bedrivits med ålderdomliga metoder av människor som levt på ett annorlunda sätt. Berättelserna utgör tillsammans en egen genre om ett svunnet Småbrukarsverige och om landsbygdens original, människor som gått mot strömmen genom att inte fullt ut infoga sig i det moderna samhället. Skildringen av Erik och Sigvard fokuserade exempelvis till stor del på hur deras jordbruk bevarade en gammaldags kulturbygd med stora naturvärden. Åkrarna bearbetades med hästkraft, korna handmjölkades. ${ }^{20}$ Hos Sture och Karl-Uno Caremalm blandades världarna: på gården fanns både traktor och mjölkmaskin, men åkarna bearbetades även med hästkraft. Skildringen fokuserar dock främst på landskapet och samspelet mellan människor och natur, inte på egenheten med ett jordbruk som drivs av två syskon. ${ }^{21}$ Ifråga om syfte går 
det att dra paralleller mellan dessa skildringar och Sune Jonssons fotografiska porträtt av landsbygdens avfolkning under 1960- och 1970-talen, eller folklivsforskaren Dan Korns skildringar av möten med "märkliga människor i ålderdomliga miljöer", särskilt i Västergötland. Korn nämner för övrigt i förbifarten att flera av de miljöer han dokumenterat befolkats av syskon i olika kombinationer: "ett brödrapar, en bror och en syster och i några fall upp till sex ogifta, hemmaboende syskon". ${ }^{22}$ Janken Myrdal har pekat på det stora allmänna intresset för serien om Erik och Sigvard och Dan Korns böcker och ställer frågan vad som ligger bakom detta. Han lyfter fram det historiska intresset för det orörda. Gårdar och miljöer framstår som "öar i tidens ström, där allt har förblivit som det en gång var", även om verkligheten kunde vara mer sammansatt och långtifrån alltid så samtidsfrånvänd. ${ }^{23}$

I den mån syskonjordbruk har uppmärksammats har de med andra ord ramats in i en berättelse om ett ålderdomligt jordbruk och ett gammalmodigt levnadssätt. Tidsperspektivet har inte sällan öppnats upp mot gångna sekler och syskonen har framställts som de sista av sin sort, en slags sista utpost av det samhälle Vilhelm Moberg beskrev där allting gick i gamla hjulspår. Den smått arkaiska tonen spiller över på syskonhushållet som företeelse: inte nog med att de har haft en gammaldags livsföring, de har dessutom blivit kvar på gården med sina syskon. Därigenom framstår syskonjordbruket i sig som något ålderdomligt. Statistikern Nils Wohlin, som i början av 1900-talet analyserade förändringar i bönders generationsväxlingar, förfäktade en liknande uppfattning. Han menade att "syskongemenskapen blifver allt mindre utmärkande för allmogeklassen" och att "brukandet af familjegården i gemensamhet eller bolag numera är sällsynt mellan vuxna arfvingar". ${ }^{4}$ Om Wohlins uppfattning är riktig bör exemplen ovan ses som en kvarleva från ett äldre bondesamhälle, men hur väl stämmer denna bild? Hittills har jag bara beskrivit en handfull fall som är svåra att generalisera. För att komma vidare måste vi lyfta blicken och vidga perspektivet. Hur såg familj och hushåll ut förr i tiden? 


\section{Familjens sammansättning - den långsiktiga utvecklingen}

Den internationella forskningen om familj och hushåll är mycket omfattande och svåröverskådlig. Den spänner över århundraden, nationer och regioner och är uppdelad på flera forskningsdiscipliner: historia, antropologi, sociologi, etnologi. Denna mångfald av infallsvinklar har inneburit att det existerar parallella och inte sällan överlappande begrepp och terminologier, vilket ibland kan försvåra jämförelser. I skilda forskningstraditioner finns en uppsjö benämningar på olika familjekonstellationer, varav långtifrån alla fått en etablerad översättning till svenska. ${ }^{25}$ Begrepp som stem family, joint family, multiple family, extended family, simple family, patriarchal family och unstable family förvirrar ofta mer än de klargör. ${ }^{26}$ På en mycket allmän nivå går det dock att göra en grundläggande distinktion mellan å ena sidan kärnfamiljer, som enbart består av ett par med barn, och å andra sidan utvidgade familjer, vars grund ofta var ett par med barn men som även omfattade ytterligare släktingar: föräldrar, fastrar, mostrar, farbröder, morbröder, syskon, syskonbarn eller andra. Oavsett form var familjen oftast grunden för hushållet, men detta kunde också vara utökat med till exempel tjänstefolk. ${ }^{27}$

En central fråga i tidigare forskning är hur förhållandet mellan kärnfamiljer och utvidgade familjer utvecklats över tid. Grovt kan två breda inriktningar urskiljas. Huvudtesen inom den första är att familjeformerna genomgått stora förändringar. En tidig förgrundsfigur i denna inriktning var den franske sociologen Frédéric Le Play, som på grundval av egna empiriska studier i mitten av 180o-talet lanserade en indelning i olika familjetyper. Den stora skiljelinjen i Le Plays verk går mellan vad han uppfattade som en traditionell, utvidgad familjetyp - ett gift par med barn, den ena makens föräldrar samt ibland även ogifta syskon och andra nära släktingar - och en kärnfamilj enbart bestående av ett gift par med barn. Den förra framställde han som ett eftersträvansvärt ideal präglat av gemenskap och solidaritet, och han kopplade särskilt samman den med traditionella bondesamhällen i Europa. Kontrasten var 
skarp till den enligt Le Play svaga och individualistiskt präglade kärnfamiljen. Den såg han som en modern skapelse, tätt sammanlänkad med en framväxande industribefolkning och delvis förorsakad av övergången till lika arvsrätt. ${ }^{28}$ Därmed lade Le Play grunden för den inflytelserika tankegången att 1800-talets samhällsförändringar successivt underminerade hävdvunna familjeband: de utvidgade familjerna blev ovanligare, medan kärnfamiljerna ökade i betydelse. ${ }^{29}$

Föreställningen om en övergång från utvidgade familjer till kärnfamiljer, med 1800-talet som vattendelare, bestod som en grundläggande del i europeiskt tänkande under flera decennier. ${ }^{30} \mathrm{I}$ olika form återfinns den hos en lång rad moderniseringsteoretiker, som Max Weber, Ferdinand Tönnies och Émile Durkheim, men också Karl Marx och Friedrich Engels. ${ }^{31}$ Weber argumenterade för att samhällsutvecklingen under 1800-talet försvagade släktrelationernas betydelse och upplöste den större hushållsgemenskapen. ${ }^{32}$ Ur ett allmänt perspektiv har förändringarna setts som en maktförskjutning från familjeöverhuvuden till enskilda individer och således som en central del i individualiseringsprocessen. Kärnfamiljen har också betraktats som tätt knuten till det moderna samhällets framväxt. På 1950-talet hävdade exempelvis Talcot Parsons att kärnfamiljen var bäst anpassad för migration och social rörlighet, aspekter som enligt honom utgjorde grunden för det moderna samhället. Parsons resonemang byggde outtalat på uppfattningen att familjen i äldre samhällen var utvidgad. ${ }^{33}$

Att idén om familjens förändrade sammansättning fick en sådan ställning berodde långtifrån alltid på gedigna vetenskapliga studier av historiska samhällen. Adam Kuper framhåller att flera av de klassiska moderniseringsteorierna snarast formulerades utifrån en upplevd samtida samhällsomdaning. Det framväxande moderna samhället definierades i detta sammanhang framför allt som en kontrast till en föreställning om hur det traditionella samhället såg ut. ${ }^{34}$

På 1960-talet började den etablerade uppfattningen om familjeformernas långsiktiga utveckling utmanas på bred front. I den nya forskningsinriktning som växte fram flyttades dock fokus från förändringar under 1800-talet till förhållanden under framför allt 
1600- och 1700-talen. Teorin om en gradvis övergång från utvidgade familjer till kärnfamiljer ifrågasattes och den skarpaste kritiken kom från socialhistoriskt inriktade forskare inom Cambridge Group for the History of Population and Social Structure under ledning av Peter Laslett. De tog sin uttryckliga utgångspunkt i familjestrukturen och genomförde med hjälp av nya kvantitativa metoder ett stort antal studier av familj- och hushållsstruktur i framför allt England. Centralt för analysen var en ny och avancerad indelning i olika familjetyper. Detta klassificeringsschema, som jag behandlar mer utförligt längre fram, har alltsedan dess varit grundläggande för liknande analyser. ${ }^{35}$ På grundval av sina resultat lanserade Laslett och hans kollegor den så kallade nollhypotesen, som går ut på att familjeförhållandena varit påfallande statiska och att kärnfamiljen dominerat i England och större delen av Västeuropa sedan åtminstone 1500-talet. Utvidgade familjer var historiskt sett sällsynta och släktskapsrelationer utanför kärnfamiljens ram hade begränsad betydelse. ${ }^{36}$ Med England som utgångspunkt lades dessa resultat till grund för en omvänd tolkning av relationen mellan modernisering och familjeformation: kärnfamiljens tidiga dominans på de brittiska öarna sågs som en grundförutsättning för Englands tidiga industrialisering. ${ }^{37}$

Dessa nya rön anammades snabbt och redan efter något decennium hade tesen om kärnfamiljens universella ställning i Europa konkurrerat ut tidigare synsätt. Detta märks även i svensk familjehistorisk forskning. Historikern David Gaunt, som 1983 publicerade standardverket Familjeliv $i$ Norden, anslöt sig uttryckligen till Lasletts uppfattning och argumenterade emot synsättet att samhället förr var "baserat på ätternas kollektivitet och solidaritet" och menade att det snarare var "ett samhälle baserat på enskilda kärnfamiljer". ${ }^{38}$ Att Cambridgehistorikernas synsätt så snabbt blev tongivande berodde delvis på att de sammanföll med resultaten av angränsande forskningsinsatser om Västeuropas sociala historia. Särskilt betydelsefulla blev den ungersk-brittiske demografen John Hajnals arbeten om europeiska äktenskapsmönster före 1900-talet. ${ }^{39}$ Hajnal drog en tänkt linje mellan Sankt Petersburg och Trieste (på gränsen mellan Italien och Slovenien) och argumenterade för att 
giftermåls- och familjebildningsmönstret väster därom uppvisade flera särdrag i jämförelse med förhållanden i övriga världen. De utmärkande egenskaperna för det västeuropeiska giftermålsmönstret var tre: sena giftermål (vilket i sammanhanget innebär att kvinnorna var runt eller över 25 år), liten åldersskillnad mellan makarna och en relativt stor andel ogifta. ${ }^{40}$ Den huvudsakliga förklaringen till dessa särdrag var enligt Hajnal att man inte gifte sig förrän man hade möjlighet att förestå ett eget hushåll. De ekonomiska förutsättningarna var centrala för hushållsbildning. Medan nygifta i stora delar av övriga världen ingick i någon av makarnas föräldrars hushåll bildade de i Västeuropa ett eget, skilt från den äldre generationen. ${ }^{41}$ Det fanns därför en påtaglig risk att man fick skjuta på äktenskapet och exempelvis arbeta som dräng eller piga under en period. Därmed förband Hajnal giftermålsmönster med hushållsstruktur och underströk att kärnfamiljen i Västeuropa tidigt fick en dominerande ställning. ${ }^{42}$

Cambridgeforskarnas resultat gav upphov till en kraftig ökning av familjehistoriska studier, men deras arbetsmetoder har också kritiserats på en rad punkter. Synpunkterna har bland annat gällt att den geografiska representativiteten har brustit, att olika sociala grupper har blandats samman och att familjer i alltför stor utsträckning har betraktats som oberoende av ekonomi och andra samhälleliga förhållanden. ${ }^{43}$ Den skarpaste anmärkningen rör dock den vetenskapliga metoden. ${ }^{44}$ Forskarna inom Cambridgetraditionen har i huvudsak arbetat med tvärsnitt och analyserat familjesammansättning inom ett visst område ett enskilt år. En sådan ansats tenderar, som framför allt Lutz K. Berkner framhållit, att övervärdera kärnfamiljens betydelse och bortse från dynamiken i familjeförhållandena. Under tidigmodern tid genomgick de flesta bondefamiljer enligt Berkner flera faser, från kärnfamilj till utvidgad familj - till exempel genom att ett barn gifte sig och bildade familj samtidigt som den äldre generationen fanns kvar i gårdens hushåll - och så tillbaka till kärnfamilj när de äldre gick bort. Eftersom tiden som kärnfamilj ofta var den tidsmässigt längsta behöver en låg andel utvidgade familjer ett enskilt år inte utesluta att många familjer genomgick en utvidgad fas. ${ }^{45}$ De olika faserna 


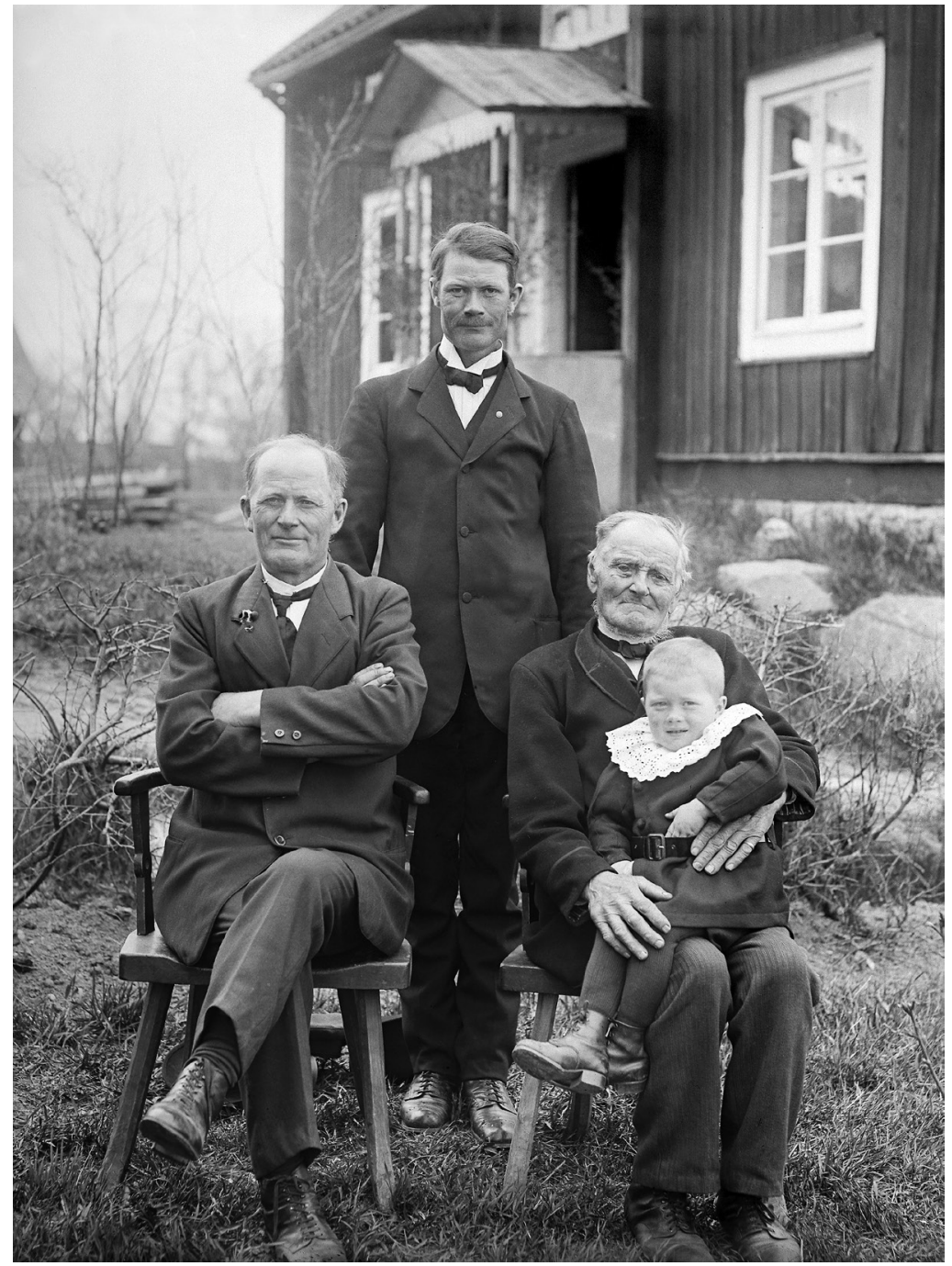

Att flera generationer levde tillsammans var länge sällsynt, vilket delvis berodde på att det var ovanligt att man nådde hög ålder. När medellivslängden ökade under 180o-talet blev släkten större. Här syns fyra generationer hos Fredrikssons i Gästre i Frösthults socken i Uppland. Foto: John Alinder/Upplandsmuseet. 
innebar dessutom att bondehushållets arbetskraftsbehov fick olika lösning beroende på var i utvecklingscykeln familjen befann sig. Var barnen små krävdes ofta anställd arbetskraft som pigor och drängar för att sköta jordbruket, medan en familj med större barn i högre utsträckning kunde sköta jordbruket på egen hand.

Kritiken mot Cambridgeforskarnas tes om kärnfamiljens dominans fick i huvudsak två effekter. En var ett starkare fokus på longitudinella studier, vilket sammanhängde med att studieobjektet i större utsträckning blev individen istället för familjen. Särskilt betydelsefullt i detta sammanhang har inriktningen på levnadsloppsanalys (life course analysis) varit. ${ }^{46}$ Den andra effekten var att studier oftare koncentrerats till kortare tidsperioder eller riktats mot nya frågor rörande migrationsmönster, handelsförbindelser och ekonomiska eller politiska förbindelser. ${ }^{47}$ Tesen om kärnfamiljens dominerande ställning har dock på flera punkter modifierats. Flera forskare har pekat på att mer utvidgade familjeformer existerade parallellt med kärnfamiljer. ${ }^{48}$ Under vissa förutsättningar kunde utvecklingen snarast gå i riktning mot fler utvidgade familjer. Baserat på ett omfattande statistiskt material från i huvudsak urbana områden i England och USA visar Steven Ruggles att antalet utvidgade familjer dubblerades mellan 1750 och 1900 . Visserligen bestod flertalet familjer under hela denna period av ett par med barn, men Ruggles beräknar att ungefär var femte familj decennierna efter 1850 inbegrep ytterligare släktingar. Förhållandena var dessutom klassberoende och de utvidgade familjerna var vanligare bland de mer förmögna i städerna. ${ }^{49}$

Om bilden av utvecklingen före sekelskiftet 1900 är sammansatt, är forskarna mer ense om utvecklingen under 1900-talet. Wally Seccombe har i en syntetiserande översikt av familjens utveckling i Europa riktat skarp kritik mot tesen om kärnfamiljens historiska dominans. Han pekar på att det var först under 1900-talet som den verkliga storhetsperioden inleddes. ${ }^{50}$ I en bred socialhistorisk översikt av europeiska förhållanden under 1900-talet visar Béla Tomka att detta mönster i princip återfinns i samtliga europeiska länder. Hushållens storlek minskade under hela seklet och de bestod i allt högre grad enbart av kärnfamiljen. ${ }^{51}$ 
Trots delvis motstridiga resultat och svårigheter att nå konsensus om den övergripande utvecklingen finns därmed, som Naomi Tadmor påpekar, en grundläggande tankegång i en stor del av den familjehistoriska forskningen om relationen mellan familj och modernitet. Oavsett om kärnfamiljen ses som en effekt av eller en förutsättning för moderniseringen är länken dem emellan given. Därmed har kärnfamiljen och den utvidgade familjen betraktats som strikt åtskilda fenomen; den förra förknippad med modernitet och den senare med traditionalism. ${ }^{52}$ I linje med denna tankegång vore det rimligast att - likt Nils Wohlin - betrakta syskonhushåll som en äldre företeelse. Tadmor ställer dock även frågan vilken verklighet som döljer sig bakom olika familjeformer och vilka släktskapsrelationer som fångas i begreppen..$^{53}$ Även om definitionen av kärnfamilj kan diskuteras och problematiseras, ställer frågan främst de utvidgade familjerna i blickfånget. Vilka var de och vad kännetecknade dem?

\section{Vertikalt och horisontellt}

När forskarna inom Cambridgegruppen på 1960-talet började jämföra hushållsstrukturen uppstod snabbt behov av ett mer preciserat schema över olika familjetyper. Den mest inflytelserika typologin utarbetades av Peter Laslett tillsammans med den amerikanske demografen Eugene Hammel. ${ }^{54}$ I sin modell lägger de äktenskapet till grund för indelning och urskiljer fem huvudgrupper:

1. Solitärer (enpersonshushåll)

2. Hushåll utan familj (ingen äktenskaplig förening)

3. Kärnfamiljer

4. Utvidgade familjer

5. Multipla familjer (mer än en äktenskaplig förening)

Laslett och Hammel reserverar termen "utvidgade familjer" för en av sina kategorier, men i praktiken sammanförs ofta grupp IV och $\mathrm{V}$ under den beteckningen. En utökning av hushållet kan dock vara av två olika slag. Vid vertikal utvidgning ingår minst en ytterligare 
släkting i en annan generation, exempelvis föräldrar som bor i samma hushåll som ett av sina barn och hans eller hennes familj. Vid horisontell utvidgning ingår minst en släkting i samma generation som hushållets basenhet (kärnfamiljen). Medan skiljelinjen mellan kärnfamiljer och utvidgade familjer är skarp kan en familj samtidigt vara både vertikalt och horisontellt utvidgad, exempelvis om den består av ett gift par med tillägg av en förälder och ett syskon till någon av kontrahenterna.

Av vertikalt och horisontellt utvidgade familjer är det utan tvekan de förstnämnda som tilldragit sig forskningens intresse, inte minst eftersom tregenerationsfamiljen setts som en särskild lösning på frågan hur generationsväxlingar genomförts. ${ }^{55}$ Att hushåll kunde vara utökade också genom att ett eller annat ogift syskon blev kvar på gården framgår ibland, men nämns mer i förbifarten. ${ }^{56}$ Över huvud taget har relationen mellan syskon sällan behandlats i social- och familjehistorisk forskning. Den amerikanska historikern C. Dallett Hemphill, som i en brett upplagd studie analyserat syskon i amerikansk historia före år 1800 , konstaterar att forskare "have nearly all written as if families consisted only of relations between husbands and wives or parents and children". ${ }^{57}$ Leonore Davidoff, som nyligen avslutat en studie av syskon i Storbritannien mellan 1780 och 1920, understryker på liknande sätt att syskon i historisk forskning länge utgjort "an absent presence". 58

Att horisontellt utvidgade familjer inte ägnats större intresse beror således på flera faktorer, men två viktiga förklaringar kan kopplas direkt till Hammel och Lasletts typografi. För det första tar deras modell inte hänsyn till familjemedlemmarnas ålder. I de flesta fall är det inte nödvändigt, eftersom hushåll vanligtvis förändras genom att barn flyttar ut eller gifter sig när de blir äldre. När sådana hushållsförändringar uteblev blir modellen mer problematisk. Det finns inget uppseendeväckande i att ett gift par med barn i unga år räknas som en kärnfamilj, men saken ter sig annorlunda om förhållandena förblev intakta under flera decennier. Hushållets medlemmar kan vara desamma, men beroende på deras ålder föreligger helt olika situationer. För det andra bygger indelningen på att familjer definieras utifrån äktenskap och relationer mellan generationer. 
Kärnfamiljen utgör modellens grundläggande basenhet. Som konsekvens tolkas enbart ett av syskonen som hushållsföreståndare, och det förutsätts att hushållets samtliga resurser - egendom, makt och status - står under hans eller hennes kontroll. Utvidgningar i sidled uppfattas därmed som självständiga individer vid sidan om kärnfamiljen. ${ }^{59}$ Leonore Davidoff pekar på att släktingar utöver föräldrar sällan ägnas någon större uppmärksamhet när skiftande hushållsstrukturer analyseras. Hon tillägger att ett viktigt skäl till detta är att källmaterial som legat till grund för studier av hushållsformer i sig har haft en normativ familjeuppfattning: en äldre man har regelmässigt definierats som föreståndare för hushållet. ${ }^{60}$

Invändningarna till trots tangerar Hammel och Laslett på några punkter diskussionen om hushåll med flera syskon. I kategorin "hushåll utan familj" ingår sådana, närmare bestämt då ogifta syskon sammanbott. I en diskussion om de mest komplexa hushållen för de ett intressant resonemang om en formation där flera gifta syskon ingått i samma hushåll, en sällsynt konstellation som de efter franskan benämner frérèche. Sådana hushåll har setts som ett uttryck för slutna bondesamhällen, där det inte har varit ett alternativ att dela upp jorden. ${ }^{61}$ Hur en frérèche ska definieras är emellertid inte helt entydigt och i sin diskussion om denna beteckning laborerar Hammel och Laslett med fyra olika definitioner, beroende på hur många av syskonen som var gifta. I en av dem går de ifrån äktenskapet som indelningsgrund och definierar frérèche som ett hushåll bestående av flera samboende syskon oavsett om ett, flera eller inget av dem är gifta. ${ }^{62}$ Denna definition omfattar flera av modellens underkategorier och förekomsten av sådana syskonhushåll har så vitt jag funnit aldrig särredovisats i någon historisk studie av hushållsformationer. ${ }^{63}$

I den här boken är det just denna uppfattning av syskonhushåll, där utgångspunkten är syskonrelationen och inte syskonens eventuella familjebildning, som står i fokus. Hur vanligt var det då att hushåll var horisontellt utvidgade? 


\section{Temporära utvidgningar}

Det finns en del studier som pekar på förekomsten av horisontellt utvidgade hushåll i urbana miljöer. I en studie av 1800-talets Glasgow visar Eleanor Gordon och Gwyneth Nair att drygt vart fiärde hushåll omfattade släktingar utanför den egentliga kärnfamiljen och att den vanligaste utvidgningen var en syster till hushållsföreståndaren eller dennes maka. ${ }^{64}$ På landsbygden tycks de horisontellt utvidgade hushållen emellertid inte ha utgjort någon större grupp under 1700- eller 1800-talet, åtminstone inte i Västeuropa. Att ogifta syskon bodde tillsammans har exempelvis varit mycket ovanligt och enligt studier av landsbygdssamhällen har sådana hushåll sällan uppgått till mer än någon enstaka procent. ${ }^{65} \mathrm{I}$ en komparativ studie av hushållsstruktur i Norge, USA och Kina under 1800-talet visar James Lee och Jon Gjerde att syskonhushåll även i sin vidaste definition var mycket ovanliga i såväl Norge som USA; i inget av länderna uppgick andelen till mer än tre procent av hushållen. I Kina var de däremot betydligt vanligare och utgjorde 1801 nära en femtedel av alla hushåll. ${ }^{66}$ Under vissa ekonomiska förutsättningar kunde dock alternativa hushållsstrukturer etableras även i Europa. För ett skogsrikt område i östra Finland visar exempelvis Beatrice Moring på förekomsten av numerärt stora hushåll, utvidgade både vertikalt och horisontellt. Fram till 1800-talets början var det inte ovanligt med gifta eller ogifta syskon till hushållsföreståndaren. När resurserna under 1800 -talet blev mer begränsade överfördes dock jorden oftare till en av sönerna och kärnfamiljer blev vanligare. ${ }^{67}$

Att syskon bodde tillsammans förefaller ha varit ovanligt i Västeuropa, och de fall som förekommer var sällan varaktiga. I en studie av familjestruktur i norra Sverige under 1700- och 1800-talen visar Inez Egerbladh att de flesta gårdar övertogs av ett av syskonen och att övriga flyttade därifrån. Under en övergångsfas kunde dock syskon till gårdstillträdaren vara kvar i hushållet, vilket berodde på att många barnkullar var utspridda över en relativt lång period. När något av de äldre barnen övertog gården fanns därför ofta minderåriga syskon kvar. Att det ett visst år fanns enstaka familjer i ett sådant skede bör således inte tolkas som att det var en bestående hushållsform, utan samboendet upplöstes enligt Egerbladh när de 
yngre syskonen nått vuxen ålder. Enbart i undantagsfall förekom att ett syskon fortsatt var inneboende hos det syskon som övertagit gården, och Egerbladh noterar att det tycks ha berott på fysiska eller mentala handikapp. ${ }^{68} \mathrm{I}$ en mikrohistorisk analys av några familjer i den baskiska byn Sare under 1800 -talet finner Marie-Pierre Arrizabalaga ett liknande mönster. ${ }^{69}$ Hon menar i likhet med Egerbladh att de ogifta syskonens närvaro speglar en ordning där endast ett barn fick överta jorden, medan övriga syskon fick tid och möjlighet att spara ihop ett kapital för en egen framtid utanför gården. På de flesta gårdar upplöstes samboendet efter några år när de ogifta syskonen flyttade. Endast på de större gårdarna i byn hände det att syskon kunde vara kvar livet ut, vilket Arrizabalaga förklarar med att dessa gårdar krävde mycket arbetskraft och att syskonen behövdes för att driva dem. ${ }^{70}$

\section{Familjejordbrukets etablering - och syskonjordbrukets?}

Syskonjordbruk tycks inte ha varit särskilt vanliga under 1700och 1800-talen. Hur ser då utvecklingen under det senaste seklet ut? Dessvärre finns det betydligt mindre forskning om hushållsstruktur under 1900-talet och det som finns gäller i första hand urbana förhållanden. ${ }^{71}$ Skiftet i forskningsintresse speglar den stora samhällsomvandling som accelererade med den begynnande industrialiseringen vid 1800 -talets slut. Städernas och industrins andel av befolkningen ökade, landsbygdens och jordbrukets minskade. När färre människor var direkt involverade i jordbruk ökade graden av marknadsintegration, vilket förändrade lantbrukarnas villkor. Innan jag går in på hushållsstrukturen under 1900-talet finns därför skäl att skissera några huvuddrag i denna utveckling.

Med början under 1870-talet drabbades den agrara ekonomin i Europa av en omfattande lågkonjunktur, främst föranledd av en ökad tillgång på billig amerikansk spannmål. I Sverige slog krisen igenom på allvar under 1880-talet, med bland annat sänkta jordvärden och ett ökat antal konkurser som följd. Det var särskilt spannmålsproducerande större jordbruk som drabbades, medan mindre och mer 
animalieinriktade gårdar klarade sig bättre. ${ }^{72}$ På sikt innebar krisen väsentliga förändringar av jordbruket på åtminstone tre punkter. För det första innebar den förändrade prisbilden en omläggning mot ett mer animaliebaserat jordbruk, koncentrerat på avsaluproduktion av mejerivaror och fläsk. ${ }^{73}$ Utvecklingen understöddes av att efterfrågan på sådana produkter ökade under perioden. ${ }^{74}$ För det andra förändrades jordbruksstrukturen. Gods och större jordbruk tappade mark till mindre och familjebaserade jordbruk. ${ }^{75}$ Delvis som en följd därav minskade för det tredje lönearbetets betydelse inom jordbrukssektorn till förmån för det familjebaserade arbetet. Jordbruket fick allt svårare att tävla med industrin om arbetskraft, och emigrationen i slutet av 1800-talet tömde effektivt landsbygden på billig och tillgänglig arbetskraft. Agrarsociologen Göran Djurfeldt pekar på det paradoxala i utvecklingen: "den 'moderna' institutionen - lönearbetet [fick] stå tillbaka för den 'för-moderna' - bonden och hans arbete". ${ }^{76}$ Till följd av dessa förändringar blev mindre och medelstora familjejordbruk, koncentrerade på animalieproduktion och baserade på brukarfamiljens egen arbetsinsats, mer betydelsefulla.

Förändringarna i slutet av 180o-talet markerade på flera sätt en brytpunkt. Den omdaning som under ett drygt sekel omvandlat jordbruket, i vad som ofta benämns den agrara revolutionen, hade kraftigt stärkt böndernas ekonomiska och sociala ställning. Gradvis växte en välbärgad hemmansägarklass fram, som vid ståndsriksdagens avveckling 1866 även nådde en politisk storhetstid i den nya tvåkammarriksdagen. Som Mats Morell konstaterar var det dock ironiskt nog just när bönderna avancerat till denna position som jordbrukets ställning började urholkas. ${ }^{77}$ Med tilltagande industrialisering och urbanisering gick jordbruket från ohotad modernäring till krisbransch, där 1800-talets starka hemmansägarekonomi fram mot 1940-talet förbyttes i statsstöd för att bönderna skulle uppnå samma levnadsstandard som arbetarbefolkningen. ${ }^{78}$

Framväxten av ett starkt familjejordbruk under 1800-talets slut var inget unikt för Sverige. Utvecklingen var likartad i stora delar av Europa och under 1900-talet befäste familjejordbruket sin ställning i stora delar av världen. ${ }^{79}$ Forskare som Harriet Friedmann har 
poängterat att också det amerikanska jordbruket vid 1800-talets slut utvecklades till att bli mer familjebaserat, vilket delvis berodde på tekniska faktorer men också hängde samman med familjejordbruket som produktionsform. ${ }^{80}$ En utgångspunkt som ofta används för att förklara bondehushållets överlevnadsförmåga är tankegångar som den ryske ekonomen A.V. Tjajanov utvecklade och som blev mycket spridda med början på 1960-talet. ${ }^{81}$ En grundtanke hos Tjajanov är att bondejordbrukets anpassningsbarhet, särskilt vad gäller arbetsinsatsen, utgör en viktig konkurrensfördel. Till skillnad från en kapitalistisk företagare strävar bonden inte efter profit, utan kan anpassa hushållets arbete efter familjecykelns faser och jordbrukets behov. ${ }^{82}$ Till detta kan läggas att familjejordbruket kännetecknas av låga transaktionskostnader, det vill säga olika typer av kostnader för förhandlingar, överenskommelser och informationshantering. Robert A. Pollak menar att alternativet att driva jordbruk med anställd arbetskraft inte bara medför lönekostnader utan även höga kostnader för att övervaka, leda och motivera de anställda. Ur en sådan jämförelse har familjebaserad jordbruksproduktion tydliga fördelar. Arbetskraften är billig, väl bekant med gårdens förutsättningar och behöver knappast övervakas. Om möjligheten att få överta gården ligger i potten finns dessutom anledning att tro att arvingen är motiverad att arbeta. ${ }^{83}$

Familjen och dess arbetskraft har haft en högst påtaglig betydelse för familjejordbruken, men hur denna familj såg ut berörs ofta ganska kortfattat. Tjajanov diskuterar familjens olika cykler, men att den i grunden består av ett gift par och deras barn tar han för givet. ${ }^{84}$ I den breda forskningen om familjejordbruk i USA och Europa görs inte heller någon större affär av familjens struktur. ${ }^{85}$ Iréne Flygare pekar på att å ena sidan historiker och å andra sidan sociologer och ekonomer sällan tycks ha stämt möte i forskningen om familjejordbruket. De senare har detaljerat undersökt familjejordbrukets olika sidor, men sällan själva familjen. Historikerna har ägnat stor möda åt att analysera förändringar i den jordbrukande befolkningens familjestruktur, men studierna har i stor utsträckning avslutats före sekelskiftet 1900 "då de ansett att bonden med familj gick i graven för ett kommersiellt jordbruk" ${ }^{86}$ I sin egen 
intervjustudie av familjejordbruk i två svenska slättbygder under 1900-talet visar dock Flygare att merparten av de studerade hushållen var utvidgade, främst i form av flera generationer som bodde tillsammans. Hon drar den tentativa slutsatsen att jordbrukets modernisering kan ha inneburit att "familjejordbruket konsolideras med släktens hjälp" ${ }^{87}$ Huvudfrågan i Flygares studie rör förhållandet mellan generationerna, men hon pekar också ut syskonrelationen som betydelsefull. Bland de jordbruk hon studerade fanns under 1900-talet flera exempel på syskonhushåll och hon framhåller syskonbandets elastiska funktion; det kunde "balansera demografiska ojämnheter i familjebildningen, lindra effekterna av att vissa syskon blir gifta och andra ogifta, samt mildra intensiva faser i familjecykeln". ${ }^{88}$ Hur dessa förhållanden förändrats över tid berörs dock inte i hennes undersökning.

Den historiska omvandlingen av bondehushållet står dock i fokus i Erik Hallbergs avhandling om den demografiska utvecklingen hos bondebefolkningen i Grindstads socken i Dalsland. Han finner flera förändringar över tid, och framhåller särskilt att bondehushållen med början runt 1860 började krympa i storlek. Bakom denna strukturella förändring finner Hallberg minskade barnaskaror, en drastisk minskning av anställd arbetskraft och allt lägre giftermålsfrekvens bland bönderna. Med utgångspunkt i bland annat Friedmanns och Tjajanovs teorier om bondejordbrukets organisering tolkar han detta som tecken på en successiv övergång till en mer familjebaserad produktionsenhet. Det renodlade familjejordbruket - med familjen som huvudsaklig arbetskraft - utkristalliserade sig allt tydligare.$^{89}$ Men Hallbergs analys av bondehushållen i Grindstad rymmer även ett annat resultat: en ökande andel jordbruk utan familjebildning. Över tid ökade antalet bondehushåll som bestod av ogifta och sammanboende syskon. Vid studiens slut 1930 utgjorde de en betydande andel av socknens gårdar, baserat på de siffror Hallberg redovisar omkring tretton procent. ${ }^{90}$

Det kan invändas att Hallbergs resultat gäller en enskild socken, som dessutom genomgick dramatiska demografiska förändringar under den tid han studerade - det var i själva verket just därför den undersöktes. ${ }^{91}$ Men var uppkomsten av syskonjordbruk en 


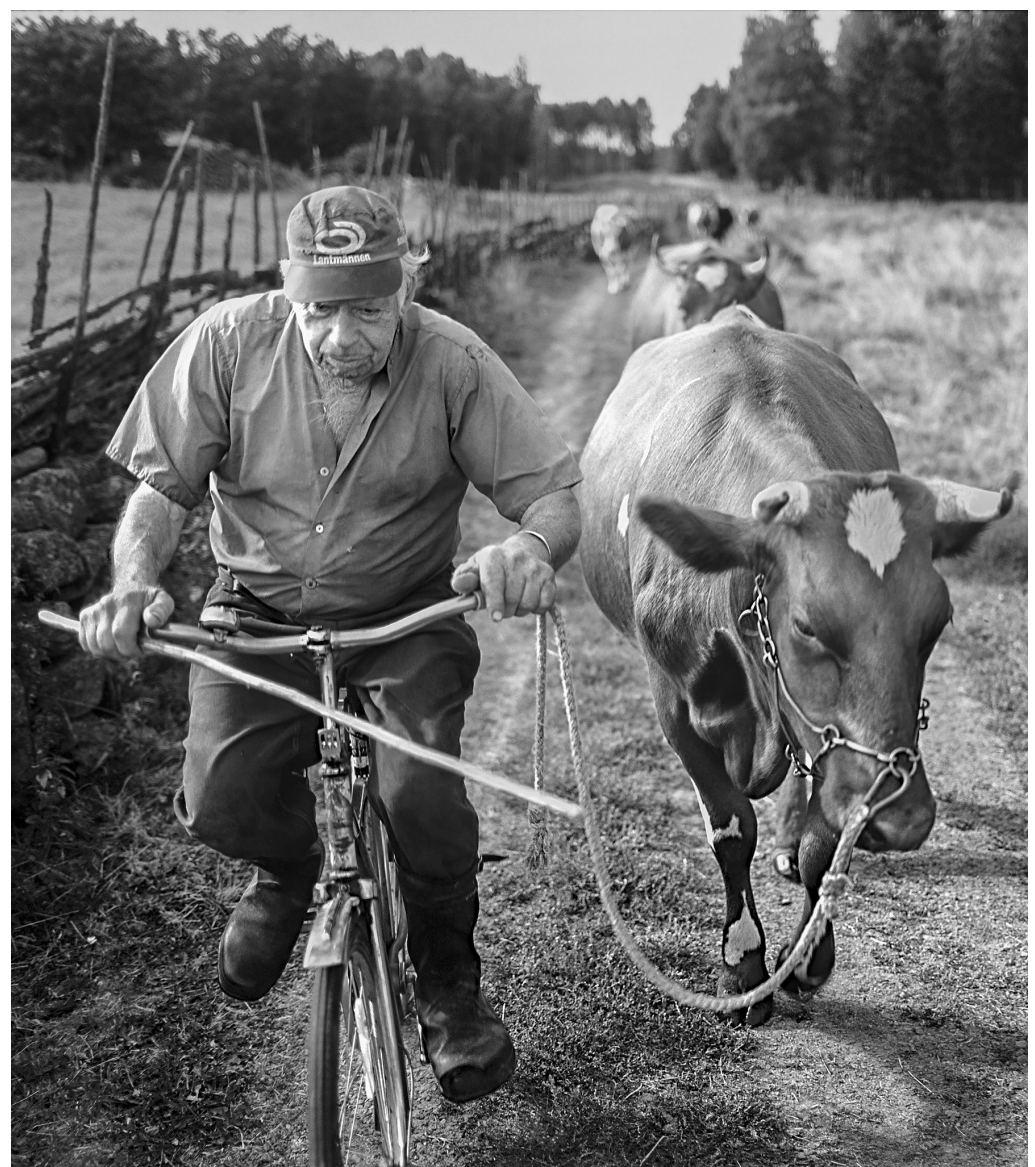

Peter Gerdehag dokumenterade i mer än 30 år vardagen på Sture och Karl-Uno Caremalms småländska jordbruk, präglat av traditionella brukningsmetoder. KarlUno tar in korna till mjölkningen. Foto: Peter Gerdehag.

demografisk säregenhet för Grindstad? Det finns inte många studier av hur hushållsstrukturen på 1900-talets landsbygd förändrades, men några forskare har tangerat frågan. I en studie av en bondedagbok från Gärdhems socken söder om Trollhättan granskar Britt Liljewall hur socknens hushållsstruktur utvecklades från 1840- till och med 1890-talet. Den viktigaste förändringen var att andelen ofullständiga familjer - med vilket Liljewall avser familjer utan antingen make eller maka - ökade från runt 14 procent i mitten 
av 1840 -talet till hela 32 procent femtio år senare. ${ }^{92}$ Bakom dessa siffror återfanns inte enbart ensamma jordbrukare. En djupare analys tyder enligt Liljewall på att många ofullständiga familjer utgjordes av "ogifta syskon [som] fortsatte att bo tillsammans och gemensamt bruka föräldragården". ${ }^{93}$ I bakgrunden anade hon stigande fastighetsvärden som gjorde att arvingarna hade svårt att lösa ut varandra.

Andra resultat tyder på att samboendet kunde bli bestående. Ulla Rosén, som studerar äldreomsorgsstrategier i Kumla socken i Närke och Herrestads härad i Skåne, finner en tydlig ökning av samboende syskon bland äldre personer under 1930-talet jämfört med vid sekelskiftet. ${ }^{94}$ Hon observerar dessutom att fenomenet var begränsat till bondeklassen..$^{95}$ Ökningen över tid framträdde enbart i Kumla, vilket kan förklaras med att giftermålsfrekvensen - antalet äktenskap i förhållande till befolkningens storlek - där sjönk betydligt lägre än i Herrestad. ${ }^{96}$ En förklaring Rosén för fram är att hemmansägarna hade formerats som klass, markerat gränsen mot den agrara underklassen och i brist på lämpliga äktenskapspartner låtit bli att gifta sig. ${ }^{97}$

Hallbergs, Liljewalls och Roséns studier har olika fokus och ingen av dem gör någon större affär av syskonhushållen. Samstämmigheten är likväl belysande. Trots att de bygger på olika källmaterial framgår i alla tre studierna att syskonhushållen inte var en del av en äldre struktur utan tvärtom något som uppstod vid ingången till 1900-talet eller något decennium därefter. Det var emellertid inte bara i Sverige som syskonhushåll framträdde. Antropologen Donna Birdwell-Pheasant har i en artikel analyserat hushållsstrukturens förändringar på irländsk landsbygd i början av 1900-talet. Hon fann en tydlig utveckling mot mer utvidgade hushåll, ett mönster som dessutom var starkare på de större gårdarna. Särskilt noterar hon att gruppen hushåll med ogifta syskon växte i betydelse på sådana gårdar. Att som Hammel och Laslett beteckna dessa hushåll som familjelösa är dock enligt Birdwell-Pheasant missvisande: "a household consisting of unmarried brother(s) and sister(s) is still very much a family household, albeit nonconjugal". 98 I många fall klarade dessa syskonhushåll dessutom av att 
genomföra en generationsväxling och hålla gården inom släkten. Samboende mellan syskon förekom dock inte enbart när alla var ogifta. På gårdar som övertagits av en gift arvinge var hushållen ofta horisontellt utvidgade med ett syskon till någon av makarna. ${ }^{99}$ Birdwell-Pheasant konkluderar att de studerade hushållen varken var kärnfamiljer eller traditionellt utvidgade familjer utan snarare en egen hushållstyp, med den utmärkande egenskapen att de "emphasized sibling solidarity". 100

I en annan studie av den irländska landsbygden pekar Damian Hannan på att det blev ännu vanligare med hushåll utan familjebildning senare under 1900-talet. Hans studie sträcker sig från 1920- till 1970-talet och visar dels att andelen gårdar med ogifta hushållsföreståndare ökade, dels att många gårdar drevs vidare med hjälp av ogifta syskon. Hannan tolkar dessa hushåll som uttryck för misslyckanden, en indikation på en rural kris. Mönstret var emellertid inte enhetligt och framträdde inte alls lika tydligt på västra Irland, där ett småskaligt familjejordbruk med lyckade generationsväxlingar bestod. ${ }^{101}$

En förändring i riktning mot att syskon gemensamt övertagit gårdar märks inte enbart i hushållsstrukturen utan även i hur generationsväxling gått till och egendom fördelats. Richard Paping, som har studerat egendomsförhållanden i Nederländerna under nära 400 år, visar att släktkontinuiteten successivt förstärktes och det tycks ha blivit allt viktigare att behålla jorden i en (manlig) släktlinje. ${ }^{102}$ Gården överfördes oftast odelad till en son, men från andra hälften av 1800-talet hände det att ogifta syskon i slutändan tog över egendomen tillsammans. ${ }^{103}$ Denna lösning "appears on first sight not to have been very modern" men blev enligt Paping allt vanligare under 1900-talet och förekom i ungefär lika stor omfattning som överlåtelse till en (gift) dotter. ${ }^{104}$ En viktig orsak var att jordbrukare generellt blev allt mindre attraktiva på äktenskapsmarknaden, men Paping pekar även på en demografisk faktor: mellan 1880 och 1960 växte den nederländska befolkningen mycket kraftigt och de stora familjerna innebar svårigheter om alla arvingar skulle upprätthålla den sociala rang det innebar att vara jordbrukare. Alternativet "remaining unmarried seemed to have been the only way for each 
child to become a farmer", konkluderar Paping. ${ }^{105}$ Syskonhushållen i Papings studie visar ingen större regional variation, däremot varierade de med gårdarnas åkerareal och de flesta återfanns på riktigt stora enheter om mer än 50 hektar. På dessa enheter var också släktkontinuiteten mer markerad, och Paping menar att familjerna tycks ha varit mycket angelägna om att hålla gården i släkten. ${ }^{106} \mathrm{I}$ en studie av ägandeförhållanden i tre västsvenska socknar mellan 1845 och 1945 fann jag ett liknande mönster. Andelen fastigheter som ägdes gemensamt av arvingar eller i form av ett sterbhus ökade där starkt under 1900-talets första hälft. Bakom företeelsen återfanns i stor utsträckning ogifta arvingar som drev gården tillsammans. Många av dessa gårdar hade gått i släkten under lång tid. ${ }^{107}$

\section{Undersökningens syfte och problemområden}

I tidigare forskning framträder syskonjordbruk knappast som en arkaisk kvarleva på väg mot sin undergång runt sekelskiftet 1900, utan snarare som något som uppstod vid denna tid. Trots att den generella utvecklingen gick mot att kärnfamiljen blev allt mer dominerande vid början av 1900-talet, förefaller syskonhushållen ha inneburit att en ny typ av horisontellt uppbyggda bondehushåll etablerades vid denna tid. Erik Hallberg pekar på det paradoxala i utvecklingen: etableringen av ett mer familjebaserat jordbruk tycks ha gått "hand i hand med framväxten av gårdar som inte längre brukades av en familj över huvud taget". ${ }^{108}$ Att syskonjordbruken framträder vid i stort sett samma tidpunkt i så olika länder som Sverige, Irland och Nederländerna antyder att det inte rör sig om en unik svensk företeelse utan snarare ett generellt drag i åtminstone det västeuropeiska bondesamhället. Även om denna studie begränsas till Sverige bidrar den därmed till att belysa ett skeende som sannolikt inte var nationsbundet.

Som framgått är inte syskonjordbruk en helt okänd företeelse i tidigare studier, men forskarna har i första hand nämnt att de förekom, utan att redogöra för hur vanliga de var, hur de var sammansatta eller hur de fungerade. Det begränsade empiriska underlaget gör dessutom att försöken att klargöra orsakssammanhang är svåra 
att bedöma. Mot denna bakgrund är syftet med denna studie att dels kartlägga syskonjordbruk som företeelse, dels förklara varför de uppkom. Mot bakgrund av forskningsläget inleds studien under 1800-talets sista decennier. För att förklara varför de etablerades hade det räckt att studera några decennier, men det finns starka skäl att låta undersökningen sträcka sig fram till 1900-talets slut. Av tidigare forskning är det oklart vilken betydelse syskonjordbruk spelade längre fram under 1900-talet och dessvärre ger inte heller jordbruksstatistiken några säkra uppgifter om det. De exempel som jag tog upp tidigare i kapitlet kan tolkas som att det nu för tiden är ovanligt att syskon bor ihop på jordbruken. En preliminär slutsats skulle då vara att syskonjordbruket inte bara hade en början utan också ett slut, en omständighet som i så fall också måste förklaras. Studien sträcker sig därför fram till 1990-talet, vilket gör att den totalt omfattar ett drygt sekel.

Studiens frågor kan delas in i tre delproblem. Det första är syskonjordbrukets utbredning. Hur vanligt var det att syskon bodde ihop på gårdarna? Finns det tydliga brytpunkter i tiden vad gäller syskonjordbrukens förekomst? Går det att fastställa när de började öka i antal? Och vad hände under 1900-talets senare del? Lika viktig som tidsdimensionen är företeelsens rumsliga utbredning. Det agrara Sverige var inte enhetligt, vare sig i slutet av 1800-talet eller under 1900-talet. Var syskonjordbrukens framväxt en allmän företeelse eller utgjorde den snarast ett regionalt mönster?

Det andra delproblemet gäller syskonjordbrukens egenskaper. Hur många syskon fanns det i hushållen? Utgjordes de flesta av brödrapar, som Erik och Sigvard, eller var det vanligare med större syskonskaror som Rundqvists i Duvemåla? Var det regel att ingen gifte sig, eller förekom det att ett eller flera syskon gifte sig? Var gårdarna i huvudsak småbruk eller stora jordbruk? Och hur väl stämmer bilden av att de var tekniskt eftersatta? Jag kommer också att diskutera om syskonjordbrukens särdrag var desamma över tid eller förändrades under 1900-talets lopp.

Det tredje delproblemet, som bygger på de två föregående, är syskonjordbrukens funktion. Hur var hushållen organiserade och hur fördelades arbetsuppgifter eller ansvarsområden? Var alla 
syskonen delägare i gården eller var ägandet samlat hos några få? På ett övergripande plan kan undersökningen av syskonjordbrukens sätt att fungera ses som ett försök till en institutionell analys, där tyngdpunkten ligger på faktorer som gjorde att de framstod som rationella i förhållande till sin samtid.

Det finns skäl att understryka att begreppet "syskonjordbruk" inte användes i samtiden utan är ett verktyg för att identifiera och analysera en viss företeelse i förgången tid. ${ }^{109}$ Några preciseringar av begreppet bör därför göras. I linje med tidigare forskning om familje- och hushållsstrukturer utgör i denna studie boendemönstret det grundläggande kriteriet för ett syskonjordbruk. Ägandeförhållandena är en viktig fråga i studien men är inte avgörande för definitionen. En gård som ägdes gemensamt av en grupp syskon men där bara ett av syskonen bodde och verkade utgör följaktligen inget syskonjordbruk. Det gör däremot en gård som ägdes av ett syskon men där flera arvingar bodde tillsammans. Jag använder vidare Hammel och Lasletts bredare definition av syskonhushåll (frérèche), vilket innebär att det är hushållets horisontella uppbyggnad som är avgörande för vad som räknas som syskonjordbruk, inte arvingarnas civilstånd. I kapitel 4 och 5, där jag diskuterar enskilda hushåll, gör jag ytterligare insnävningar av dessa kriterier, men för delstudierna i kapitel 2 och 3 räcker de gott.

\section{Individer, familjer och strategier}

En utgångspunkt för undersökningen är att syskonjordbruk är resultat av mänskligt handlande. Även om strukturella förutsättningar av olika slag - som lagstiftning och ekonomi - sätter gränser för vad som är möjligt, så uppstår hushåll och familjer inte ur tomma intet. Inom socialhistoria har begreppet "strategi" haft stort inflytande under de senaste decennierna och använts för att beskriva aktörers handlingar och handlingsmönster. ${ }^{110}$ En strategi kan sägas vara en aktörs medel för att uppnå vissa mål. Denna användning av begreppet har sitt ursprung i en inflytelserik artikel av Pierre Bourdieu, som i början av 1970-talet beskrev familjestrategier vid arv och giftermål bland franska bönder som delar av ett system 
för biologisk, kulturell och social reproduktion. Grundläggande i Bourdieus synsätt är att familjen är en handlande enhet. Handlingsmönstren kan härledas ur vad Bourdieu kallade habitus, en samling underförstådda principer som alla inom en grupp (exempelvis en familj) ovillkorligt underordnade sig. ${ }^{111}$

Begreppet "strategi" kan vara ett verktyg för att föra upp diskussioner om handlingsmönster på en abstrakt nivå och diskutera vilka målsättningar som legat bakom dem. Det har emellertid också ifrågasatts hur begreppet används och vad det bidrar med. Två av de väsentligaste invändningarna är vilka förutsättningar som finns för att nå bakom det direkta handlandet och frilägga målsättningarna bakom samt vems strategier det är som analyseras.

Den första invändningen, som rör begreppets operationalisering, är den allvarligaste. Även om det är möjligt att visa att en viss aktör eller grupp agerade på ett visst sätt, är det rimligt att anta att handlandet följde en i förväg uttänkt strategi? Går det kort sagt att utifrån resultatet av en händelse eller händelsekedja (som familjebildning, hushållsförändringar och generationsväxling) sluta sig till vilka mål de ingående aktörerna hade? Problemen är uppenbara. Att beskriva handlingsmönster som strategier riskerar att överdriva det rationella i aktörernas beslutsfattande. Ibland blev inte utfallet det planerade och i backspegeln kan ett förlopp framstå som mer logiskt än det tedde sig medan det pågick. Särskilt påtagligt är detta när långsiktiga och ibland flergenerationella handlingsmönster analyseras, eftersom historiska skeenden kan förändra de grundläggande förutsättningarna för aktörernas handlande. ${ }^{112}$ Dessutom finns en tendens att begreppet fokuserar på en elit med framgångsrika strategier och att aktörer som gjorde mindre lyckade val försvinner ur källmaterialet. ${ }^{113}$

En analys av handlingsmönstren ställer därför krav på forskaren. I en diskussion om strategibegreppets förutsättningar tar Jan Kok upp tre metodologiska förutsättningar för att kunna sluta sig till bakomliggande strategier. ${ }^{114}$ Han menar att man måste känna till: 
1. Personens eller personernas motiv, vilket inkluderar kunskap om situationsbundna värderingar.

2. Vilka begränsningar omgivningen (lagstiftningen, lokalsamhället, andra aktörer och så vidare) satte upp, samt vilka handlingsalternativ som därmed stod till buds.

3. Vilken information aktörerna själva hade tillgång till.

Eftersom dessa krav mycket sällan är uppfyllda när man gör historiska analyser är risken stor att man uttalar sig om strategierna på grundval av utfallet. Trots de metodologiska problemen argumenterar Kok för strategibegreppets möjligheter. Även om vi inte fullt ut kan tränga in i aktörernas tankevärld kan vi jämföra hur personer med liknande social och kulturell bakgrund agerade, och genom att jämföra handlingssätt i skilda situationer kan vi försöka blottlägga den strategiska delen i deras agerande. Vi kan försöka fastställa vilka begränsningar som påverkade deras agerande och vilka valmöjligheter de hade. Kok förordar en kombination av kvantitativt och kvalitativt källmaterial för att skapa en mer sammansatt grund för analysen. ${ }^{115}$ Han framhåller också värdet av att närmare studera dem som agerade annorlunda och valde nya alternativ, vilka erfarenheter och förutsättningar som möjliggjorde deras handlande och i vilken omfattning de influerade andra. ${ }^{116}$

Den andra invändningen mot strategibegreppet är vems strategier det är som studeras. Bourdieus analys förutsatte i princip en patriarkalt styrd familj där fadern dikterade villkoren för familjemedlemmarnas handlande. ${ }^{117}$ Andra forskare har använt begreppet för att diskutera individers handlingsmönster och försökt lösa upp familjen som handlande enhet. Familjen var inte homogen och ett ensidigt fokus på familjestrategier riskerar att dölja de maktförhållanden mellan äldre och yngre, män och kvinnor, föräldrar och barn, som ryms inom familjerelationerna. ${ }^{118}$ Tamara Hareven ställer frågan vems strategier som blev familjestrategier och argumenterar för att källornas tystnad om beslutsfattandet inom familjerna gör det svårt att klargöra i vilken grad familjen agerade som en kollektiv aktör. Individuella strategier kunde stå i ett intrikat förhållande till övergripande familjestrategier och en 
fördjupad analys av beslutsfattandet inom en familj kan belysa vilka effekter ekonomiska, sociala och kulturella förändringar fick på mikronivå. ${ }^{119}$ Också Jan Kok argumenterar för vikten av att närmare analysera hur beslutsprocesser såg ut inom enskilda familjer. ${ }^{120}$ Laurence Fontaine och Jürgen Schlumbohm understryker behovet av att utsträcka studiet till ibland motstridiga strategier inom familjens eller hushållets ram och konstaterar att även om familjer kan agera som en kollektiv enhet i vissa avseenden så är de i andra avseenden "a forum for centrifugal and centripetal forces alike". ${ }^{121}$

Dessa kritiska synpunkter har medfört att en del forskare har avrått från att använda strategier som analysverktyg. Theo Engelen menar att begreppet skapar mer problem än det löser och att det är rimligt att nöja sig med att rekonstruera det faktiska utfallet av människors agerande. ${ }^{122}$ I direkt anslutning till Engelens resonemang invänder Jan Kok dock att en sådan målsättning inte är nog, ambitionen måste vara att förklara olika handlingsmönster. ${ }^{123}$ Jag är ense med Kok om att man inte enbart bör sträva efter att frilägga handlingsmönster utan även efter att utröna varför människor gjorde som de gjorde. I linje med Koks resonemang är en målsättning med denna bok att studera en grupp människor som agerade på ett nytt sätt och därigenom skapade ett nytt mönster. För att möjliggöra detta kombineras kvantitativt och kvalitativt material på olika plan och jag försöker koppla beteenden till de valmöjligheter och begränsningar som kan anses ha förelegat. Även om jag i studien utgår från att aktörerna var rationella och agerade på ett förnuftigt sätt givet sina förutsättningar och tolkningsramar menar jag inte att syskonjordbruken a priori ska betraktas som resultaten av en medveten strategi. Om de var det, eller om de snarare var utfall av misslyckade strategier, är en fråga för de följande undersökningarna.

När människors eller gruppers handlande studeras sker det dock vanligen på grundval av att vissa av deras handlingar gjort avtryck i källorna och därmed är möjliga att studera. Människor har flyttat, gift sig eller på olika sätt skaffat familj och deras beteende kan analyseras. Ett kännetecknande drag hos de syskonjordbruk som här står i fokus är dock snarast avsaknaden av sådana aktiva handlingar. En utmaning ligger därmed i att studera något som 
inte sker. I en undersökning av jordbrukslandskapets förändringar under 1900-talet diskuterar kulturgeografen Anders Wästfelt hur vissa förväntade händelser ifråga om familjebildning och generationsväxling uteblivit. Han betecknar dem som "icke-händelser", ett begrepp hämtat från geografen Torsten Hägerstrands arbeten. ${ }^{124}$ Både Wästfelt och Hägerstrand understryker betydelsen av att analysera det som inte sker, förväntade men uteblivna handlingar som ger upphov till nya mönster och olika former av tröghet. ${ }^{125}$ Denna utgångspunkt är enligt min mening fruktbar och gör det möjligt att se även icke-händelser som delar av nya mönster. Att en förväntad handling - familjebildning, äktenskap, flytt - inte ägde rum kan bero på att den aktivt och medvetet valdes bort, men Wästfelt understryker att icke-händelser inte behöver innebära avsaknad av intention. ${ }^{126}$

Med utgångspunkt i detta resonemang kommer strategibegreppet användas för att föra upp de handlingsmönster som framträder i undersökningen på en mer abstrakt nivå. Begreppets fördel är, som bland andra Malin Nilsson har påpekat, att det både ser de historiska aktörerna som rationella beslutsfattare och tar hänsyn till strukturella begränsningar. ${ }^{127}$ Centralt för min analys är därför vilka avsikter som låg bakom olika handlingar. Resonemanget kan konkretiseras utifrån den fråga som här står i centrum. Var syskonjordbruken ett resultat av icke-händelser, det vill säga en följd av handlingar som i sig inte syftade till att flera syskon övertog gården - till exempel att föräldrarna inte hade utsett en ensam arvinge eller att fler arvingar inte flyttade eller gifte sig? Eller var de ett resultat av medvetna strategier där familjer eller individer utifrån strukturella förutsättningar agerat efter vissa målsättningar?

\section{Bokens upplägg}

Jag har i undersökningen tillämpat ett sammansatt angreppssätt med flera analysnivåer, materialtyper och metoder. Studien består av fyra delstudier redovisade i lika många kapitel. Undersökningarna bygger på sinsemellan skilda källmaterial och de mer handgripliga diskussionerna om metodologiska angreppssätt samt materialets 
förtjänster och brister redovisas därför i respektive kapitel. Den övergripande målsättningen är att delundersökningarna gradvis ska fördjupa resonemanget. Perspektivet rör sig från en övergripande nationell nivå till en mycket konkret nivå i det sista av de fyra kapitlen: det enskilda hushållet och dess medlemmar. Avsikten är varken att skriva mikro- eller makrohistoria, istället menar jag att en blandning av olika nivåer i undersökningen fördjupar analysen. Upplägget gör att vissa upprepningar av mönster och teman är ofrånkomliga eftersom de framträder i flera olika material. Samtidigt ger detta en möjlighet att successivt pröva resultatens giltighet. Framkommer likartade resultat i delstudier baserade på olika material och undersökningsnivåer kan de förstärka varandra. Om resultaten däremot är motstridiga bör slutsatser formuleras mer försiktigt.

Kapitel 2 handlar om ägandeförhållanden inom det svenska lantbruket under 1900-talet. Fokus ligger särskilt på samägda fastigheter, det vill säga gårdar som ägdes av flera personer tillsammans. Kapitlet bygger i huvudsak på statistiska uppgifter, utredningar och offentligt politiskt tryck. Förutsättningarna för samägande förändrades på ett genomgripande sätt under 1800-talets lopp, vilket utgör en viktig bakgrund till förhållandena under 1900-talet. Jag diskuterar även uppkomsten av en jordbrukspolitik inriktad på familjejordbruk och vilket familjebegrepp denna politik byggde på. Ett genomgående tema i kapitlet är hur samägande av jordbruksfastigheter uppstod, och jag visar att detta över tid utvecklade sig till ett allvarligt problemområde i statens ögon.

Även i kapitel 3, som handlar om arvspraktiken, rör jag mig på den nationella nivån. Om syskonjordbruken blev vanligare över tid bör det ha förändrat hur generationsväxlingar genomfördes. I kapitlet analyserar jag tre nationella enkäter om arvssedvänjornas utformning från 1900-talets första hälft. Med utgångspunkt i detta källmaterial diskuterar jag också betydelsen av förändringar i giftermålsmönstret under 1800 -talet och vilket förklaringsvärde demografiska förhållanden kan tillmätas.

I kapitel 4 flyttas analysen ner till lokal nivå. På grundval av bland annat folkräkningsmaterial analyserar jag hushållsstruktur 
i tio socknar vid sju tillfällen mellan 1870 och 1991. Förutom att klargöra hur vanliga syskonjordbruk var studeras också hur antalet varierade över tid och mellan olika områden samt vad som kännetecknade dem. Förutom hushållets sammansättning studerar jag även jordbrukets förutsättningar.

Resultaten från kapitel 2, 3 och 4 ger en bild av den övergripande utvecklingen men säger mindre om hur syskonjordbruken i sig fungerade. I kapitel 5 anlägger jag därför ett inifrånperspektiv på grundval av ett trettiotal intervjuer med fokus på förhållanden inom enskilda syskonhushåll. Dessa berättelser gör det möjligt att uppmärksamma förhållanden som inte går att avläsa i skriftliga källor: syskonens relationer till varandra, kärleksförbindelser, arbetsförhållanden och hur vardagen på gården gestaltade sig.

I det avslutande sjätte kapitlet sammanfattar jag de viktigaste slutsatserna och diskuterar hur syskonjordbrukets uppkomst bäst bör förklaras. 